TITLE:

\title{
Japanese Market Development Programs under PL 480 in the late 1950s: Focus on Wheat and Rice
}

$\operatorname{AUTHOR}(S):$

ITO, Atsushi

CITATION:

ITO, Atsushi. Japanese Market Development Programs under PL 480 in the late 1950s: Focus on Wheat and Rice. Agricultural History 2021, 95(2): 245-275

ISSUE DATE:

2021-04

URL:

http://hdl.handle.net/2433/266838

RIGHT:

(C) 2021 Agricultural History Society; This is not the published version. Please cite only the published version. この論文は出版社版でありませ ん。引用の際には出版社版をご確認ご利用ください。 
Japanese Market Development Programs under PL 480 in the late 1950s: Focus on Wheat and Rice

\author{
ITO Atsushi
}

\begin{abstract}
The US Government concluded Public Law (PL) 480 Title I agreements with Japan in 1955 and 1956. The purpose of this article is to reexamine Japanese market development programs under PL 480. The findings are as follows: (1) Japan was regarded as a potential market for rice and other US commodities as well as wheat; (2) Judging from Japanese and US government documents, USDA officials did not intend to replace Japanese rice with US wheat; (3) Market development plans for US rice had failed due to the damaging effect on diplomatic relations with Southeast Asia and the contradiction with Japan's food policy. Among the crucial factors that decided the market development program results, this article emphasizes the importance of recipient countries' policies and multilateral relations.
\end{abstract}

ITO Atsushi is associate professor of comparative study of agricultural history at Kyoto University. He is the author of Nihon nōmin seisaku shiron [Japan's peasant policy in the wartime and postwar periods] (Kyoto: Kyoto University Press, 2013).

Corresponding author: ITO Atsushi (ito.atsushi.6e@kyoto-u.ac.jp) 


\section{Introduction}

In the autumn of 1957, the US secretary of agriculture Ezra T. Benson made a three-week trip around the world. During his stop in Japan, he conducted an onsite inspection of US-funded food programs and "saw mobile kitchens, mounted in buses, and equipped with loudspeakers, and the Japanese housewives coming around with their children strapped to their backs, to learn how to prepare bargain wheat dishes." ${ }^{1}$ This cooking demonstration was part of market development programs for US wheat imported under the Agricultural Trade Development and Assistance Act of 1954, or Public Law 480 (PL 480). PL 480 legitimized the sale of US surplus agricultural commodities in return for local currencies and mandated that accumulated funds would be used for overseas development of commodity markets, economic development in recipient countries, and a variety of other purposes that would benefit the United States during the Cold War.

Numerous studies have been published on postwar US food aid policy, but several important issues remain unexplored. First, while previous studies have carefully examined the food aid policies of the United States and the on-the-ground conditions in countries receiving food aid, policy-making in recipient countries has received scant attention. ${ }^{2}$ Second, existing studies have focused exclusively on the bilateral relations between the United States and recipient countries, but US trade policy was linked in such a way that requires scrutiny that moves beyond the study of bilateral relations. Despite the official US position that food aid did not impede trade relations, US food aid inevitably caused conflicts with other food-exporting countries. Third, it is necessary to examine the relationship between crop varieties and recipients' dietary habits more carefully. In Central America, for instance, where white corn was used most prominently in the daily diet (in tortillas, for 
example), aid recipients sold yellow corn from the United States to local chicken feeders and used the money to buy the white corn they preferred. ${ }^{3}$ It seems probable that such a conflict between crop varieties and dietary habits arose from other cereals. Above all, the global increase in bread consumption is often cited as an influence of food aid on traditional eating habits. ${ }^{4}$ Since US wheat for food aid is not limited to hard (bread) wheat alone, there is still some room for reexamination of the matter.

This study investigates Japanese market development programs under PL 480 in the late 1950s. Japan was the biggest recipient of PL 480 aid until India concluded an agreement with the United States in August 1956. Concerning market development programs under PL 480, Susan George described Japan as "one of the best investments" for the United States. ${ }^{5}$ In the Japanese literature, some journalists and scholars emphasized "the US wheat tactics" that intended to replace Japanese rice with US wheat for export market expansion. ${ }^{6}$ Although some historical studies on Japanese dietary habits hold the same view, others have affirmed the stagnation of the per capita consumption of wheat and the continuous increase in that of rice until the early 1960s (Figure 1). ${ }^{7}$

Such confusion suggests the need for a reconsideration of US food aid in Japan. First, Japan's policy-making has received little attention. The claim that the United States conspired to shift Japanese dietary habits from rice to wheat (the so-called "US wheat tactics") is based on documents from the wheat growers association (an executive organ of market development for US wheat) and interviews with officials from the United States and Japan. ${ }^{8}$ Opponents refute this claim with statistical data but have never analyzed the policy-making process. This article utilizes previously unused government documents on Japanese market development programs. Official documents from the US and Japanese 
governments contain detailed descriptions of Japan's reactions to the market development programs. $^{9}$

Second, international political circumstances in the 1950s have not been carefully considered. Concerning US agricultural policy, Trudy Huskamp Peterson emphasized the major role of political considerations in determining US agricultural policy under the Eisenhower administration, but existing studies on PL 480 agreements with Japan have ignored political factors. ${ }^{10}$ Even in cases touching on the political context, PL 480 was connected directly with Japan's rearmament policy from a bilateral relations viewpoint. ${ }^{11}$ In addition, studies on Japanese agricultural history that have criticized "the US wheat tactics" focused on domestic factors without considering international affairs. By contrast, studies of international relations reveal that US policy toward Japan was an inseparable part of a broader strategy for Southeast Asia and China during the Cold War era. ${ }^{12}$ Nevertheless, even in this field, most scholars have treated PL 480 agreements with Japan from a bilateral perspective. Although William Borden regarded PL 480 as an extension of the previous surplus disposal policy, this claim ignored a turnaround in US strategy for Asia (see Section 2). Sayuri Shimizu, meanwhile, pointed out that among surplus commodities cotton and rice posed the most complex challenge for the Eisenhower administration, but she referred only to the bilateral contradiction between the export of US cotton to Japan and the export of Japanese textile goods to the United States. ${ }^{13}$ By contrast, this study analyzes the multilateral conflicts among the United States, Japan, and other food-exporting countries.

Third, scholars of PL 480 have neglected Japanese foodways and crop varieties. Previous studies have assumed that US wheat exports were the hard wheat used for bread 
and thus focused primarily on market development programs regarding the Westernization of Japanese dietary habits. ${ }^{14}$ US wheat exports to Japan, however, consisted mostly of soft and semi-hard wheat in the 1950s. In Japan, soft wheat is used as an ingredient of udon (Japanese noodles), and semi-hard wheat is used in ramen (Chinese noodles). Furthermore, existing studies focused narrowly on wheat and the supposed shift away from rice imports, but Japan imported US rice as well under PL 480. ${ }^{15}$ And just as with wheat, rice varieties and foodways mattered. These points will be discussed in detail in Section 3 and Section 4. PL 480 was passed by the 83rd Congress in July 1954. The act contained three titles. Title I legitimized the sale of surplus agricultural commodities for local currencies on condition of safeguarding "usual marketing." The accumulated local currencies could be used for the following purposes: market development for US agricultural commodities, purchase of strategic materials, military procurement for common defense, purchase of goods for other friendly countries, grants for trade and economic development, payment of US obligations, loans for trade and economic development, and international educational exchange. Title II authorized donations of food for famine relief and other assistance. Title III regulated internal and foreign donations and barter transactions for strategic materials. This study analyzes market development programs funded by the accumulated local currency under Title I. Even though PL 480 had multifunctional aspects (such as agricultural policy, foreign policy, and humanitarian assistance), in the 1950s implementation of the program was motivated almost exclusively by the urgent need to dispose of surpluses and, consequently, humanitarianism and economic development were merely useful and convenient by-products of a pragmatic policy. ${ }^{16}$ Although PL 480 shifted to foreign aid under the name "Food for Peace" in the 1960s, the act was chiefly a 
domestic agricultural policy in the 1950 s, the primary period of interest here. ${ }^{17}$ Concerning market development, Mitchel B. Wallerstein has pointed out that this function spurred a substantial portion of domestic support for PL 480. ${ }^{18}$ Although Japanese market development is widely publicized as a successful example, considering the export volume shown in Figure 2, it is hard to believe that the market development program expanded the export market for US wheat. How can we resolve this contradiction?

This study reveals the actual conditions of the market development programs for wheat and rice in Japan. It interprets the execution of market development programs in terms of the interactions among the donor (the United States), recipient (Japan), and other food-exporting countries. It also go beyond a simple, one-sided story of US imposition and pay close attention to crop varieties to grasp the dynamics of US food aid policy in the Cold War era. The following sections (1) survey the development of US food assistance for Japan since the occupation era; (2) examine the market development program for wheat; (3) trace the market development program for rice, which has not previously been investigated; and (4) summarize the findings and explore some implications for the study of US food aid policy.

\section{Food Assistance for Japan: From Emergency Aid to Concessional Sale}

The United States initiated a food aid program with Japan as a countermeasure against the food crisis under occupation. The defeat in World War II triggered an acute food shortage due to a lack of labor, a scarcity of fertilizer because of air attacks on nitrogen plants, and the interruption of rice imports from decolonized Korea and Taiwan. In metropolitan areas, food stockpiles were limited, and food riots were a serious concern for 
occupation authorities. ${ }^{19}$ To help provide emergency aid in Japan and other areas of US occupation, the United States created the Government Aid and Relief in Occupied Areas (GARIOA) program in 1946, which transitioned into the Economic Rehabilitation in Occupied Areas (EROA) program in 1948. After Japan regained sovereignty in 1952 and the Korean War reached a ceasefire in 1953, food assistance began to transition from emergency measures to formal trade policy. During the political and economic transition, US and Japanese officials regarded a concessional sale of US food crops as a countermeasure that could resolve both US agricultural problems and Japan's economic problems. Though US farm production expanded rapidly after the war due to technological innovations and price supports, export trade remained sluggish. Major causes of inactivity included: overpriced crops due to government price supports; chronic dollar deficits in importing countries (the so-called dollar gap problem); and decreasing demand for food reserves because of the Korean War ceasefire. ${ }^{20}$ In the 1950s mounting overstocks of farm products developed into a pressing political issue in the United States (Table 1). In Japan, the dollar gap problem had been a serious impediment to economic reconstruction. Japan had compensated for a huge trade deficit via a "special procurement" deal to supply the US military with manufactured goods during the Korean War. The armistice meant a loss of Japan's main dollar-based income source. Thus, the Japanese government promoted industrial development to earn foreign currency and agricultural development to save foreign currency; it was unfeasible to achieve economic reconstruction by domestic funds alone.

In July 1953, when the Korean War ceasefire was concluded, the US Congress approved the addition of Section 550 to the Mutual Security Act of 1951. Section 550 
authorized the sale of surplus agricultural commodities in local currency on the condition that these sales should not substitute for existing commercial trade. The proceeds from sales could be used to provide US military assistance, purchase goods or services in friendly countries, provide loans or grants-in-aid to increase production in friendly countries, develop new markets, and purchase materials for US stockpiles. The US government concluded the Section 550 agreement with Japan in March 1954. According to the agreement, the United States would sell surplus wheat and barley for 18 billion yen (equivalent to $\$ 50$ million), the accumulated local currency would be used for the offshore procurement of goods and services in support of US military assistance programs $(\$ 40$ million), and the United States would provide a grant-in-aid to Japan's defense industry (\$10 million). For the Japanese government, the anticipated economic benefits did not pan out due to strict restrictions dictating that funds be used for military purposes and a small proportion of grant-in-aid to the total sale proceeds. ${ }^{21}$ In addition, the Section 550 agreement with Japan caused international friction with Canada and Australia, who competed with the United States for wheat exports to Japan. In the 1950s US soft and semi-hard wheat competed with Australian wheat, while the Japanese market for hard wheat was dominated by Canada (Table 2). The Canadian government described the deal as export-dumping, and Australian authorities expressed their indignation that other suppliers had not been consulted. ${ }^{22}$

After the failure of Section 550, Congress passed PL 480 in July 1954. The act authorized various uses of the funds ranging from industrial and military development to food and famine relief, which prompted an interdepartmental dispute over jurisdiction. The USDA considered PL 480 to be surplus disposal policy, while the Department of State 
regarded it as foreign policy. The USDA had the upper hand in the early going. After the passage of PL 480, an executive order gave the USDA Title I authority, and jurisdiction over the Foreign Agricultural Service (FAS) was transferred back to the USDA from the State Department. ${ }^{23}$ PL 480 had an immediate effect on US wheat exports. The percentage of total wheat exports under Title I was 27 percent in 1955, 37 percent in 1956, and 64 percent in $1962 .^{24}$

The US and Japanese governments concluded their first agreement in May 1955 and their second in February 1956. As Japan's national budget for agriculture gradually decreased in proportion to an improving food situation, the Ministry of Agriculture and Forestry (MAF) became an aggressive advocate for PL 480. The MAF expected to secure funding from the World Bank and a PL 480 Title I loan; the intention was that most of the loan would be spent on agricultural development projects. ${ }^{25}$ After the interministerial negotiations in October 1954, the Japanese government proposed a loan equivalent to $\$ 133$ million for economic self-reliance programs, such as financing the Export-Import Bank of Japan, developing the defense industry, and funding agricultural development. ${ }^{26}$ During the visit of Prime Minister Yoshida to the United States in November 1954, the governments came to a general agreement. The sale of surplus agricultural commodities under Title I was equivalent to $\$ 85$ million (in addition to an equivalent of $\$ 15$ million granted under Title II). Thirty percent of the accumulated local currency would be allotted to the US government, and Japan contracted to buy surplus rice, which was not included in its original offer. Given the US government's concern over decreasing demand for American farm products, the proportion of the loan allotted for agricultural development was limited to 10 percent of the total. ${ }^{27}$ The formal signing of the agreement was delayed 
until May 1955 because of the resignation of the Yoshida Cabinet in December 1954 and difficult negotiations on the conditions for the loan repayment. However, the new Hatoyama Cabinet maintained a policy of introducing foreign funds. ${ }^{28}$ The second Title I agreement (equivalent to $\$ 65.8$ million) was signed in February 1956. The course of events clearly shows the Japanese government's positive attitude toward PL 480. While Aaron Forsberg has claimed that Japan was less enthusiastic about the program than their American benefactors, Japanese government documents indicate that the Japanese offered a proposal far above the US estimates for the acquisition of the development funds. ${ }^{29}$ Moreover, it is noteworthy that the US government not only decreased the total amount of the Title I loan but also reduced the proportion put toward agricultural development. This is in stark contrast to PL 480 agreements with India under the Johnson administration, which emphasized self-help and gave priority to agricultural development. ${ }^{30}$ This prioritizing of domestic agricultural interests over the economic development of the recipient country demonstrates the characteristics of PL 480 under the Eisenhower administration.

In contrast to Section 550, US-Japan PL 480 agreements did not cause a deep conflict with the Canadian government. Canada had concluded a trade agreement with Japan in March 1954 that guaranteed equal treatment concerning exports to Japan. ${ }^{31}$ An Australian official, however, informally indicated his government's displeasure over the first Title I agreement. ${ }^{32}$ When Australia entered into trade negotiations with Japan in 1956, wheat became the chief obstacle. ${ }^{33}$ In 1957 the Japanese government concluded a trade agreement with Australia and, consequently, withdrew an offer of a third PL 480 Title I agreement with the United States. ${ }^{34}$ The Agreed Minutes of the Agreement on Commerce between Australia and Japan stipulated that Japan would ensure an opportunity for 
Australian soft wheat in the case of a violation of normal commercial practice (such as surplus disposal). ${ }^{35}$

Thus, the United States made two PL 480 Title I agreements with Japan, with sales of surplus agricultural commodities reaching \$150.8 million. Tables 3 and 4 provide details of the Title I agreements with the top sixteen of twenty-seven countries for the first two years of the program. Compared to other countries, the characteristics of Japan are as follows. First, regarding total amounts, Japan was the biggest recipient of Title I commodities. As stated above, Japan's balance of payments was in deficit, and food accounted for 25 percent of its total imports at the time. ${ }^{36}$ Given that food importation under PL 480 did not demand dollar payments, Japan hoped for the maximum number of commodities. Second, regarding the items under consideration, Japan ranked second for wheat and first for cotton. Existing studies have argued exclusively about wheat exports; however, the amount of wheat exported was less than the amount of cotton. Moreover, Japan was the third biggest recipient of US rice. Figure 3 delineates the expenses of market development as of September 1958. Admittedly, the largest sum of money was allocated to wheat, but its share in the total amount was merely 31 percent. Figure 3 demonstrates that the FAS intended to expand exports of cotton, tobacco, soybeans, and wheat and emphasized international trade fairs.

Third, regarding the use of local currencies, the largest amount for market development (\$3.3 million) was allotted to Japan. More noteworthy is the fact that Japan was the biggest recipient ( $\$ 108.8$ million) of the economic development loans. In contrast to Japan, most local currency in both Yugoslavia and South Korea was allotted to military procurement, and the proportion of economic development loans was 7 percent for 
Yugoslavia and zero for South Korea. In effect, the PL 480 agreements with South Korea and Yugoslavia retained the military nature of the Section 550 agreement, whereas the main purpose of the PL 480 agreement with Japan was to encourage economic development. A large economic development loan was in accord with US foreign policy as well as Japan's economic policy. After the ceasefire in the French-Indochina War on July 1954, the Eisenhower administration shifted foreign policy toward Japan from the buildup of military forces to the enhancement of political and economic stability as an anti-Communist strategy. ${ }^{37}$ As a result, the PL 480 agreements with Japan varied greatly from the agreement with South Korea, which was at the forefront of the Cold War. Although Borden claimed that PL 480 was virtually identical to Section 550 and stipulated that 95 percent of the local currency financed offshore procurement, Table 4 shows otherwise. ${ }^{38}$ Existing studies have often connected PL 480 with Japan's rearmament, but the "military procurement fund" in Japan (and the UK) was mainly used to build dependent housing for US forces and had nothing to do with Japan Self-Defense Forces. ${ }^{39}$ Those who have interpreted PL 480 as an extension of Section 550 ignore the changing phases of the international situation in the 1950s.

\section{Market Development Program for Wheat}

The Japanese government started attaching importance to wheat production in the 1930s. In 1932, in the middle of the Great Depression, the MAF set up a five-year plan for increasing wheat production with the aims of improving balance of payments and raising farm income. The plan was successful: wheat production increased by 50 percent and Japan achieved wheat self-sufficiency in $1937 .{ }^{40}$ When rice imports from the Japanese colonies 
and occupied areas were interrupted by the worsening war situation, domestic wheat acquired even greater importance. In 1942 the Japanese government enacted the Food Control Law, and rice and wheat came under state control. After defeat in World War II, Japan obtained food aid from the United States, and, as a result, per capita consumption of wheat rose steeply from 9.5 kilograms in 1939 to 25.3 kilograms in 1948 (Figure 1).

In the postwar period, various agencies began encouraging the use of flour. The Ministry of Health and Welfare (MHW) intended to shift from an overdependence on rice to a more balanced diet. In 1950 the MHW cooperated closely with occupation authorities in implementing a school lunch program (composed of donated wheat and dried skim milk) to improve nutritional deficiency of schoolchildren. ${ }^{41}$ The Food Agency of the MAF, meanwhile, sought to increase wheat imports $(\$ 83 / \mathrm{MT})$ instead of the more expensive rice (\$164/MT) in an effort to distribute low-priced staple food. ${ }^{42}$ In the agricultural extension service (introduced into the MAF by occupation authorities in 1948), home-life extension workers promoted wheat use for improvement of dietary habits in rural areas. Thus, because the Japanese authorities themselves introduced various measures to encourage wheat consumption, it is clear that the United States did not need to adopt any "tactics." There were differences among the ministries in their promotion of wheat, however. The MAF, which had taken responsibility for the food policy since the prewar period, regarded wheat promotion as an extension of existing activities for a stable supply of cheaper food. By contrast, after the war the MHW pushed the boundaries of this field in close collaboration with occupation authorities for the purpose of nutritional improvement. These two ministries had contrasting responses to US wheat promotion.

Between September and December 1954 (shortly after the passing of PL 480), the 
US wheat mission-which consisted of officials in the Grain and Feed Division of the Foreign Agricultural Service (FAS), the Miller's National Federation, and the Oregon Wheat Growers League (OWGL) — conducted market surveys in Egypt and Asia. ${ }^{43}$ Of Japan, the mission reported that, despite the official policy to maximize wheat consumption, Japanese agencies attached little or no importance to market development projects. ${ }^{44}$ As discussed earlier, the Japanese government initiated negotiations on the PL 480 agreement in the hope that the total amount of the Title I loan would be dedicated to economic development projects. Against the Japanese plan, Wolf Ladejinsky (an agricultural attaché) requested to allocate market development funds to the USDA as a bargaining chip to obtain agricultural development loans; thus, the market development funds were approved in the PL 480 agreements with Japan. ${ }^{45}$

In May 1956 contracts for wheat projects were finalized between private organizations in both countries. On the US side, OWGL was the contracting party. On the Japanese side, organizations were divided along jurisdictional lines: the Japan Nutrition Association (an extra-governmental organization of the MHW) and the National Food Life Improvement Association (an extra-governmental organization of the MAF). Although the largest amount of funds was allocated to the advertising campaign, the quarterly reports of OWGL emphasized the importance of the kitchen demonstration buses (popularly called "kitchen cars" in Japan) and the training for bakers. The kitchen cars were overseen by the MHW and demonstrated "balanced meals" to homemakers. During the visit of the US wheat mission in 1954, Ōiso Toshio (director of Nutrition Division of the MHW) presented the kitchen cars, which were converted from used Tokyo metropolitan buses, and explained the national development plan. According to Ōiso, after conflict with the MAF, OWGL 
strengthened their relationship with the MHW and stressed the potential influence of the kitchen cars; thus, eight buses were constructed from the market development fund. ${ }^{46}$ These buses traveled 89,143 kilometers and provided 3,523 demonstrations, reaching more than 370,000 homemakers in a year. ${ }^{47}$

Regarding the bakers training program, OWGL gathered 141 bakers from each of the forty-six prefectures and provided a three-month course focusing on the utilization of US semi-hard wheat. Graduates of the program were scheduled to teach baking methods to local bakers. It was estimated that 10,000 people attended these local lectures within two months. The program was so successful that OWGL planned to train Burmese bakers in Japan if the United States concluded a PL 480 wheat agreement with Burma. In addition, OWGL sent data on the wheat campaign in Japan to East Pakistan as reference material to promote wheat consumption. ${ }^{48}$ Considering these activities, OWGL regarded the wheat campaign in Japan as a model for the expansion of wheat export to other parts of Asia.

Whereas the United States established a good working relationship with the MHW, negotiations with the MAF faced tough challenges. In April 1955 K. Yamamoto (a counselor in the MAF) called J. C. Dodson (an agricultural attaché) at the US embassy to express particular interest in two parts of the market development program. One was wheat processing, which would promote the ministry's objective of increasing wheat consumption. Yamamoto indicated that the ministry would welcome the dispatch of an American wheat-processing expert to Japan. Wartime Japan's milling capacity had decreased from 53,111 barrels in 1944 to 22,686 barrels in $1945 .{ }^{49}$ Small mills were built as a temporary measure, but the modernization of milling facilities had become an urgent problem for the Japanese by the 1950 s. The second project was corn processing. ${ }^{50}$ Japan was a large 
importer of US corn but mostly for livestock feed. Yamamoto referred to his prewar observations of corn utilization in Korea and Manchuria, making special mention of cornstarch. However, corn was excluded from the PL 480 Title I agreement, and the MAF submitted a request for wheat projects in July 1955. In the MAF's plan, more than half the funds were allotted to research and processing facilities; only 20 percent went to “improving dietary habits," including kitchen cars. ${ }^{51}$ Regarding this proposal, Ambassador John M. Allison expressed the critical view that expenditure for machinery and equipment violated the principle of market development funds. Among the nine projects presented, he judged three as "unsatisfactory" and two as "questionable." 52 Thus, in September 1955, the MAF proposed a revised plan amounting to the equivalent of $\$ 1.25$ million. In the revised plan, two-thirds of the funds were allotted to promoting wheat consumption through the home life improvement extension service. The plan claimed that using the existing organization was the most effective way to achieve this end. ${ }^{53}$ The United States refused this proposal, and the market development funds for wheat were distributed to the advertising campaign (equivalent to $\$ 200,000)$, kitchen cars $(\$ 150,000)$, training for bakers $(\$ 100,000)$, and the home life improvement extension service $(\$ 60,000){ }^{54}$

These events indicate the different views on the wheat campaign among the FAS, MAF, and MHW. They all shared the same objective of expanding wheat consumption but differed on how to achieve it. The MAF intended to appropriate the market development funds to existing activities such as facility improvement and the home life improvement extension service. The FAS, however, stressed methods unfamiliar to the MAF, such as the advertising campaign and kitchen cars. As a result, negotiations between the FAS and the MAF continued for several months. By contrast, the MHW-a newcomer to food 
policy-responded quickly to the US wheat mission in 1954 and used funds for the nationwide development of kitchen cars. With the cooperation of the FAS, the MHW succeeded in expanding into food policy.

Although OWGL considered the Japanese case as a model for expansion into Asian markets, the export volume of US wheat to Japan failed to grow in the 1950s. Given the circumstances, how did the American embassy staff evaluate the market development programs supervised by the FAS? Correspondence shows that there were major differences of opinion. Shortly after the programs were launched, the US Embassy's counselor for public affairs, Joseph S. Evans Jr., pointed out that the FAS activities overlapped with some of the objectives of the United States Information Service (USIS). A more vital concern was that the promotion campaign encouraged Japan to spend more dollars of its badly needed foreign exchange, which was inconsistent with the US policy for Japanese economic self-reliance. ${ }^{55}$ In addition, interim chargé d'affaires J. G. Parsons cast serious doubts on the feasibility of the projects. He claimed that Japan's purchases of American agricultural products would be governed more by availability and government-planned use of foreign exchange than by a promotion campaign planned by the United States. In conclusion, he mentioned the "revision or elimination" of the FAS proposals. ${ }^{56}$

"A Fresh Start with Japan," a report submitted to the Department of State on September 1956, reflected the views of the embassy staff. In the report, market development projects were deemed likely to fail because they did not fully account for Japanese domestic economic policy. The report highlighted the market development projects' assumption that if consumer demand was stimulated for particular commodities, then imports would increase as well. Such an assumption ignored "the overriding 
importance of Government planning and foreign exchange availability in the formulation of Japanese import programs." If these projects increased demand, Japanese consumers and American producers would eventually be irritated should the Japanese government fail to respond to pressure for such imports. ${ }^{57}$ As stated above, Japan reluctantly accepted market development programs as a bargaining chip to obtain agricultural development loans. The embassy staff was well aware of Japan's economic situation and considered that the volume of American exports was determined by foreign currency allocation rather than consumer demand; thus, FAS's market development programs were received unfavorably. Regarding specific items, Parsons pointed out that the cotton project conflicted with the Japanese policy of increasing domestic consumption of synthetic fibers to diminish dependence on imported raw materials. ${ }^{58}$ Furthermore, it was reported that programs for dairy and poultry would be refused since Japan was actively promoting the domestic livestock industry. ${ }^{59}$ Although historian Kristin Ahlberg has claimed that PL 480 commodities conditioned Japan to accept US dairy products, the Japanese government had its own internal priorities that often conflicted with PL 480. Prior to the PL 480 agreement, for instance, Japan had passed the Dairy Promotion Law in 1954, which put a higher priority on the protection of the domestic livestock industry. ${ }^{60}$

While market development programs that were inconsistent with Japan's policies were certain to fail, the American embassy singled out wheat as an exception because the Japanese government sought to promote its consumption. ${ }^{61}$ Nevertheless, some reports from diplomatic establishments contradicted the self-praise in the OWGL reports. In the 1950s the Japanese market for hard wheat as an ingredient for bread was dominated by Canada, and US semi-hard wheat ranked below Canadian hard wheat for use in bread 
(Table 2). Therefore, the US plan for the wheat promotion campaign included developing new uses for soft and semi-hard wheat rather than hard wheat ${ }^{62}$ and encouraging the Japanese baking industry to consider using softer wheat. ${ }^{63}$ Although the per capita consumption of wheat increased by 166 percent in comparison with the wartime period, bread was no more than a rice substitute at that time (Figure 1). The report from the Food and Agriculture Organization of the United Nations (FAO) on the effect of food surpluses on Japan's economy demonstrated that the income elasticity of demand for wheat was negative and that the availability of more wheat might have reduced demands for barley. ${ }^{64}$ That is, in the late 1950 s wheat was ranked as superior to barley and inferior to rice.

Bread consumption in Japan was affected by the rice price on the free (black) market. Thus, bread production decreased by 10 percent from 1955 to 1957 after two years of bumper rice crops. In addition, growth in the use of a new automatic electric rice cooker adversely affected bread consumption. ${ }^{65}$ A Japanese newspaper reported that the average Japanese family spent 373 yen on bread ("the king of substitute food") in August 1956 compared to 617 yen in May 1955. Moreover, 3,000 of 15,000 bakers and 37,000 of 150,000 retail shops had gone "bankrupt" between the summer of 1955 and January $1957 .{ }^{66}$ In 1957 an agricultural attaché to the embassy, W. D. Termohlen, submitted a special report on the decline of the bread industry to the USDA. According to the report, the Japan Bakers Federation requested that the Japanese government and the government party reduce the government's selling price of imported wheat. This was refused, however, because it would adversely affect the price of indigenous wheat and, furthermore, because the import markup on wheat helped cover the deficit in the Food Control Special Account. ${ }^{67}$

Although bread makers faced a difficult situation, the proportion of noodles (43 
percent) was larger than bread (34 percent) in terms of the end-use of wheat. ${ }^{68}$ Furthermore, because rice crops had a limited influence on noodle consumption, Consul General George H. Emery promised that Japan's noodle industry would remain a good customer of US wheat in the future. ${ }^{69}$ It is noteworthy that diplomats recognized that a promising field for US wheat was not western food (hard wheat for bread) but traditional Asian food (soft wheat for udon and semi-hard wheat for ramen). Although the FAS attached importance to international trade fairs, as shown in Figure 3, the impact of the USDA's exhibition at the 1958 international trade fair in Osaka was "practically nil." Japanese observers expected to see something American at the American exhibit but only found ordinary Japanese household products such as noodles (wheat), soy sauce (soybeans), and soap (tallow). ${ }^{70}$ The American embassy staff expected to expand wheat consumption within the framework of traditional Japanese eating habits rather than by inducing a change in people's dietary habits. ${ }^{71}$ Despite the Japanese government's promotion of wheat consumption and market development projects by the FAS, the export volume of US wheat stagnated in the late 1950s and increased suddenly in the 1960s (Figure 2). It is impossible to interpret this phenomenon as having resulted from market development projects; rather, drastic changes in Japanese agricultural and food policy were the decisive factor.

In 1961 the Japanese government enacted the Agricultural Basic Law to modernize Japan's agricultural industry and to phase out production of wheat and soybeans, which were not considered good prospects for international competition. ${ }^{72}$ Consequent to the shift in agricultural policy and coupled with severe crop failure in 1963, domestic wheat production rapidly diminished (Figure 4). From 1964 onward Japan shifted to a favorable balance of trade. ${ }^{73}$ The resolution of the foreign exchange shortage enabled Japan to 
replace domestic wheat with imported commodities. Furthermore, import markup on wheat became more important due to chronic deficits in the Food Control Special Account. ${ }^{74}$ Regarding varieties of US wheat, a key contribution to the expansion of export was not soft and semi-hard wheat, which US diplomatic agencies regarded as promising (Figure 2). In the 1950s, because US hard wheat came from ports in the Gulf of Mexico, it could not compete with Canadian hard wheat, which was exported from Pacific ports. To solve this problem, Great Plains wheat growers obtained a needed reduction in rail freight rates to transport wheat to the West Coast for export. ${ }^{75}$ On the other hand, to reduce income disparity between Japan's declining agricultural sector and its growing industrial sector, the Japanese government's purchase price on rice continued to rise after the $1960 \mathrm{~s}^{76}$ Following a steep rise in the price of rice, the production of bread in Japan increased from 470,402 MT in 1960 to 711,100 MT in $1966 .{ }^{77}$ In sum, the rapid expansion of US wheat exports to Japan in the 1960s resulted from the reduced cost of hard wheat after the resolution of the foreign exchange shortage and a decline in domestic agriculture due to rapid industrial growth in Japan, and not from the market development projects in the 1950 s. $^{78}$

\section{Market Development Program for Rice}

Wheat consumption in Japan was closely interrelated with the nation's rice policy. Although previous studies fail to notice, the United States exported rice to Japan under PL 480, and the Foreign Agricultural Service (FAS) elaborated a plan for the market development of US rice. This fact refutes the "US wheat tactics" hypothesis that claims the United States intended to replace Japanese rice with US wheat. However, it is undeniable 
that the market development of US rice failed, largely because of the profound effect of rice-exporting countries in Southeast Asia.

In the 1950s Thailand and Burma were the primary US competitors for rice exports to Japan, a competition encouraged by the United States (Figure 5). After the establishment of the People's Republic of China in 1949 and the expansion of US containment policy to "Communist China," the United States sought to shift Japanese trade toward Southeast Asia. Japan argued otherwise. During a visit to the United States in 1954, for instance, Prime Minister Yoshida called for a relaxation of the trade restriction against China by saying that Japan would build bridges between "the free world" and "Communist China," but he was flatly refused. ${ }^{79}$ In the US strategy toward Asia, Japan was cast as the "workshop of Asia," and Southeast Asia was regarded as an import market for food and raw materials and an export market for manufactured goods to provide Japan with an economic alternative to Northeast Asia. ${ }^{80}$ From the 1930s Japan had established the "yen bloc" in Northeast Asia. After its defeat in World War II, however, Japan lost its semi-colonial state, Manchuria, and colonies such as Taiwan and Korea. Northeast Asia declined sharply as a destination for Japanese export, from 42 percent (between 1934 and 1936) to 9 percent (between 1951 and 1953), whereas Southeast Asia increased from 19 percent to 36 percent during the same period. ${ }^{81}$ In addition, Japan's export of manufactured goods to Southeast Asia was closely related to a US domestic problem. In the mid-1950s an influx of cheap textile goods from Japan had become a political problem in the United States. Given that several states were considering differential import restrictions on Japanese goods, the US government regarded developing countries in Southeast Asia as a more appropriate outlet for cheap Japanese goods..$^{82}$ 
Moreover, trade between Japan and Southeast Asia had the advantage of foreign exchange. In the 1950s all Southeast Asian countries were in the non-dollar area. Former British colonies, including Burma, belonged to the sterling area. Whereas Japan suffered chronic dollar deficits, sterling reserves increased cumulatively under the payment agreement between the UK and Japan, which was revised in January 1954 and enabled Japan to accept payments in sterling when trading with places outside the sterling area. ${ }^{83}$ In trade negotiations with the UK in 1955, Japan agreed to make an effort toward the expansion of payment to the sterling area. ${ }^{84}$ Other Southeast Asian countries, including Thailand, concluded open-account agreements with Japan, wherein cash settlement was arranged at the end of a term and not at every transaction. Although open-account agreements suit countries suffering from foreign exchange shortage, it has the effect of reaching a contracted equilibrium because of the incentive to minimize the balance of trade. That is, Japan had to expand imports from open-account countries to raise exports to these countries. Although Japan developed a close economic relationship with Southeast Asian countries through war reparations and economic cooperation after the 1960 s, there were only two agreements (with Burma and the Philippines) in the mid-1950s. Under these circumstances, it was for rice that Japan had the greatest demand among Southeast Asian commodities. As shown in Figure 6, rice accounted for most of the imports from Thailand and Burma. Since Japanese foodways had long preferred sticky Japonica rice from California, Taiwan, and so on, the import of US rice was more desirable in terms of the food policy. The import of fluffier Indica rice from Southeast Asia, however, was more important to trade policy. As the American embassy staff rightly pointed out (see Section 3), Japanese import programs were determined by foreign exchange availability; therefore, 
trade with the non-dollar area was given a higher priority.

While the Japanese government emphasized rice import from Southeast Asia, Japan was also the biggest customer of US cotton, wheat, soybeans, and rice in 1954. The United States exported rice to Japan, totaling \$49 million of its total export of \$106 million. ${ }^{85}$ However, regarding rice export to Japan under PL 480 Title I, considerable disunity existed within the Eisenhower administration. Since Japan attached foremost importance to trade with Southeast Asia under strict restrictions on trade with China, it was feared that the import of US rice exceeding "usual marketing"-as stipulated in PL 480 Section 101(a) - impeded trade with Southeast Asia. In October 1954, at an interagency meeting to discuss the PL 480 Title I agreement with Japan, all agencies (except the USDA) opposed the inclusion of rice, and it was agreed that the matter should be taken to the White House for resolution. ${ }^{86}$ At the Cabinet meeting, the director of the Foreign Operations Administration (FOA), Harold E. Stassen, recommended that rice should not be included in the initial program but that a clause should be written enabling Japan to make its normal dollar purchases of US rice. He explained that this would free Japan to make its other purchases from Southeast Asian countries. Countering Stassen, Secretary of Agriculture Ezra T. Benson claimed that the United States faced a heavy rice surplus and that the country was trying to gain its share in the Japanese rice market; moreover, rice could be included without encroaching on the Southeast Asian share. Secretary of State John F. Dulles disagreed with Benson, noting the harmful effect on Burma, Thailand, Pakistan, and Taiwan should their Japanese market decrease. Secretary of the Treasury George M. Humphrey then emphasized that including rice in the program would merely serve to displace dollar sales. At the conclusion of the meeting, President Eisenhower expressed the 
view that a compromise could be worked out to include "a small amount of rice." 87 Concerning the PL 480 agreement with Japan, a deep antagonism developed between the USDA, which considered the purpose of the act to be surplus disposal, and State, which felt concern over harmful effects on diplomatic relations. The president's arbitration indicates that the initial intention of PL 480 was primarily to serve as surplus disposal rather than foreign policy or aid.

Although the first Title I agreement with Japan contained rice equivalent to $\$ 15$ million, contrary to Benson's optimistic expectations, US rice export to Japan severely affected rice-exporting countries such as Thailand and Burma, which depended on the rice trade for 70-80 percent of their foreign exchange earnings. The Thai ambassador to Washington stated that it was illogical for the United States to assist Thailand with military and economic aid while at the same time destroying the markets on which Thailand depended. In Burma, one Cabinet member called the US disposal plan "a kiss of death." A Burmese source stated that dumping US rice in Asia would force Burma to turn to Communist China. ${ }^{88}$ Responding to these economic and political reactions at the Council on Foreign Economic Policy, the USDA and the State Department agreed to revise US policy in April 1955. In the revised policy, precautions would be taken to avoid driving down prices, and the United States would consult with the governments of Burma, Thailand, and South Vietnam prior to implementing concessional sales. ${ }^{89}$ When the United States and Japan concluded the second Title I agreement in February 1956, US rice was excluded because of these concerns, as well as a bumper rice crop in Japan. After the change of policy, however, U Kyaw Nyein (an acting foreign minister of Burma) complained of their straitened circumstances. He claimed that the only way for the United States to improve the 
Burmese situation was to assist Burma in finding markets for its rice, or, at the very least, to refrain from disposing of US rice surpluses in Asian markets. Otherwise, he feared that within five years Burma would be sucked into the Soviet orbit. ${ }^{90}$ His concern was not groundless. During the visit of Kono Ichiro (Japan's minister of agriculture and forestry) to the United States in May 1956, he said Japan was planning for its normal purchasing of Burmese and Thai rice as a part of the national policy of cementing better trade and other relations with Southeast Asian countries. He added, however, that Burma was becoming increasingly difficult to deal with, particularly because of its increasing rice trade with the Russians. $^{91}$

While the concessional sale of US rice to Japan disappeared, the FAS did not intend to abandon the Japanese market. According to the original FAS plan, proposed in January 1957 amid the wheat campaign, Japan was regarded as "the largest single potential rice market for the US." Under the plan, trade delegations from both countries would intensively study the following problems: the adequacy of existing facilities; the adaptability of varieties, grades, and quality of US rice; consumer reaction to varieties and grades of US rice; and the development of a publicity campaign in Japan in connection with rice consumption. ${ }^{92}$ The Japanese government, however, rejected the proposal because of their recent abundant rice crop, the potential negative effects on trade with Southeast Asia, and a contradiction with the national policy that encouraged the consumption of wheat rather than expensive rice. ${ }^{93}$ The FAS revised its plan, but the American embassy was skeptical about its feasibility because of Japan's domestic policies. ${ }^{94}$ The Japanese government was indeed reluctant but tolerated the plan on the condition that promotional activities be minimized. ${ }^{95}$ Eventually, an insignificant amount 
was allocated to rice projects from the market development funds (equivalent to $\$ 1,900) .{ }^{96}$ As a result, market development for US rice failed. In the late 1950s, then, the Japanese government stressed a tightening of economic ties with Southeast Asia over expanding the presence of US rice in the Japanese market. After the 1960s the economic importance of the rice trade declined as a result of the agreements for reparations and economic cooperation with Southeast Asian countries. Due to an increased yield of domestic rice, however, it became unnecessary for Japan to import rice at all by the end of the 1960s. Thus, an attempt to establish a permanent market for US rice in Japan ended in failure.

\section{Conclusion}

This study has shown that the trajectory and outcomes of PL 480 aid depended as much on the domestic policies of recipient countries as on the aims of the United States. Two broader implications can be derived from the case of Japan. First, concerning the decisive factors behind the execution of PL 480, the Eisenhower administration gave overriding priority to domestic agricultural interests over foreign relations and economic development of recipient countries. While previous scholars have recognized these motivations, it is a noteworthy that actual events were by no means determined by a one-sided decision with no room for negotiations. Instead, the case of Japan demonstrates that unilateral interests of the United States were inevitably restricted by the governmental policies of recipient countries and the multilateral conflicts among other food-exporting countries. This situation suggests that it is not enough to examine US policymaking alone; instead, it is essential to consider recipient countries' policies as well as multilateral relationships in the Cold War era. 
Second, concerning the impact of US food aid on the recipient country's eating habits, the case of Japan shows that the actual effect diverges widely according to crop varieties. The argument in existing studies that US food aid caused an increase in wheat consumption through the spread of bread consumption is based on the assumption that US wheat was hard wheat. Singer, Wood, and Jennings, however, pointed out that bread only became a problem in those areas where wheat was not a normal crop and did not grow well, such as in tropical Africa. ${ }^{97}$ By contrast, Japan achieved wheat self-sufficiency in the 1930s, and domestic soft wheat was included in daily diets as noodles prior to PL 480 . Moreover, Singer, Wood, and Jennings pointed out that bread became a "status" product in many developing countries, but in Japan it was regarded as a lesser substitute for rice in the 1950s and 1960s. ${ }^{98}$ US wheat had a minimal effect on food habits in those areas already using soft or semi-hard wheat in the daily diet for noodles. ${ }^{99}$ Meanwhile, in the case of Japan, rice was a vital export commodity for developing countries in Southeast Asia, the pivotal area in the US Cold War strategy toward Asia. It seems that economic and political characteristics of rice conflicted sharply with the diplomatic requirements of food aid. As shown in this discussion, the approach used in this article- involving a careful examination of (1) recipient countries' initiative, (2) multilateral relations, and (3) crop varieties_can be applied to future research on the complex dynamics of food aid.

\section{NOTES}

The author appreciates insightful comments from the editor and two anonymous reviewers, which greatly improved an earlier version of this manuscript. This work was supported by 
JSPS KAKENHI Grant Numbers JP16K07924 and JP18H02290.

1. Ezra Taft Benson, Cross Fire: The Eight Years with Eisenhower (Garden City, NY: Doubleday, 1962), 366.

2. On policymaking in the United States, see Peter A. Toma, The Politics of Food for Peace: Executive-Legislative Interaction (Tucson: University of Arizona Press, 1967); Trudy Huskamp Peterson, Agricultural Exports, Farm Income, and the Eisenhower Administration (Lincoln: University of Nebraska Press, 1979); Mitchel B. Wallerstein, Food for War-Food for Peace: United States Food Aid in a Global Context (Cambridge: MIT Press, 1980); Burton I. Kaufman, Trade and Aid: Eisenhower's Foreign Economic Policy 1953-1961 (Baltimore: Johns Hopkins University Press, 1982); Kristin L. Ahlberg, Transplanting the Great Society: Lyndon Johnson and Food for Peace (Columbia: University of Missouri Press, 2008). On the conditions of food aid, see Susan George, How the Other Half Dies: The Real Reasons for World Hunger (1976; repr., Harmondsworth: Penguin Books, 1991); Rachel Garst and Tom Barry, Feeding the Crisis: U.S. Food Aid and Farm Policy in Central America (Lincoln: University of Nebraska Press, 1990).

3. Garst and Barry, Feeding the Crisis, 111-12. Concerning the case of the African sub-Saharan region, see Hans Singer, John Wood, and Tony Jennings, Food Aid: The Challenge and the Opportunity (Oxford: Oxford University Press, 1987), 106.

4. Paul Susman, "Exporting the Crisis: U.S. Agriculture and the Third World," Economic Geography 65, no. 4 (Oct. 1989): 306; Garst and Barry, Feeding the Crisis, 60.

5. George, How the Other Half Dies, 198. See also Jerome M. Stam, "The Effects of 
Public Law 480 on Canadian Wheat Exports," Journal of Farm Economics 46, no. 4 (Nov. 1964): 812; Charles M. Hardin, Food and Fiber in the Nation's Politics, Vol. 3 (Washington, DC: Government Printing Office, 1967), 36; Vernon W. Ruttan, United States Development Assistance Policy: The Domestic Politics of Foreign Economic Aid (Baltimore: Johns Hopkins University Press, 1996), 197.

6. In 1978 a nationwide Japanese TV broadcast made this assertion for the first time. The program was published as a book a year later; Takashima Teruyuki, Nihon shinkō Amerika komugi senryaku [Invasion of Japan: The US Wheat Tactics] (Tokyo: Ie no hikari kyōkai, 1979). In this article, Japanese names are rendered with family surname first.

7. On "US wheat tactics," see Kishi Yasuhiko, Shoku to nou no sengoshi [Postwar History of Food and Agriculture] (Tokyo: Nikkei Publishing, 1996), 96-98; Suzuki Takeo, "Amerika komugi senryaku” to nihonjin no shokuseikatsu ["The US Wheat Tactics" and Japanese dietary habits] (Tokyo: Fujiwara shoten, 2003), 51-63; Barak Kushner, Slurp! A Social and Culinary History of Ramen: Japan's Favorite Noodle Soup (Leiden: Global Oriental, 2012), 210-11; George Solt, The Untold History of Ramen: How Political Crisis in Japan Spawned A Global Food Craze (Berkeley: University of California Press, 2014), 76-77. For the opposing view, see Mochida Keizō, Nihon no kome [Rice in Japan] (Tokyo: Chikuma shobō, 1990), 159; Hasemi Takahiro, Sengo nihon no mugi seisaku to nokyō mugirui kyōhan [Postwar Japan's Wheat Policy and the Agricultural Joint Selling Association for Wheat and Barley] (Tokyo: Nōrin tōkei shuppan, 2012), 11; Ogiwara Yuki, "Seikatsu kairyō fukyūin no showa 20-30 nendai no eiyō shidō no igi to kōseki" [Significance and Achievements of Nutrition Guidance by Home Life Improvement 
Extension Service in the 1950s], Nogyō oyobi engei 88, no. 12 (Dec. 2013): 1179.

8. Takashima, Nihon shinkō Amerika komugi senryaku.

9. Some scholars have researched Japanese government documents, but their concern was not the execution of market development but the PL 480 negotiation. Mizumoto Tadatake, “Amerika yojō nōsanbutsu shori kōshō: Nihon no kaitsuke" [A Note on Parley with the USDA on the Surplus Disposal Problem under PL 480], Ningen to shakai 12 (Sept. 2001), 170-178; Shirakizawa Asahiko, “Sengo shokuryō yu'nyū no teichaku to shokuseikatsu kaizen" [The Fixation of Postwar Food Import and Improvement of the Food Life], Nogyōshi kenkyū 36 (Mar. 2002), 17; Asai Yoshio, "Sekai ginkō no tainichi seisaku no keisei: 1951-1956 (2)" [Formative Years of the World Bank's Lending Policy toward Japan: 1951-1956 (2)], Seijō daigaku keizai kenkyū 215 (Jan. 2017), 24-37.

10. Peterson, Agricultural Exports, Farm Income, and the Eisenhower Administration, xi-xii; Mizumoto, "Amerika yojō nōsanbutsu shori kōshō"; Shirakizawa, “Sengo shokuryō yu'nyū no teichaku to shokuseikatsu kaizen”; Asai, "Sekai ginkō no tainichi seisaku no keisei."

11. Darrell G. Moen, “The Postwar Japanese Agricultural Debacle,” Hitotsubashi Journal of Social Studies 31 (July 1999): 35; Kushner, Slurp! A Social and Culinary History of Ramen, 212; Solt, The Untold History of Ramen, 75; Fujihara Tatsushi, Kyūshoku no rekishi [History of School Lunch] (Tokyo: Iwanami shoten, 2018), 183.

12. Michael Schaller, "Securing the Great Crescent: Occupied Japan and the Origins of Containment in Southeast Asia," Journal of American History 69, no. 2 (Sept. 1982): 392-414; William S. Borden, The Pacific Alliance: United States Foreign Economic Policy 
and Japanese Trade Recovery, 1947-1955 (Madison: University of Wisconsin Press, 1984); Hatano Sumio, “Tōnan ajia kaihatsu o meguru Nichi-Bei-Ei kankei: Nihon no koronbo puran ka'nyū (1954 nen) o chūsin ni” [Japan-US-UK Relations Centering on the Development of Southeast Asia in the 1950s], Nenpo kindai Nihon kenkyū 16 (Nov. 1994), 222-225; Sayuri Shimizu, Creating People of Plenty: The United States and Japan's Economic Alternatives, 1950-1960 (Kent: Kent State University Press, 2001).

13. Shimizu, Creating People of Plenty, 112.

14. Borden, The Pacific Alliance, 185; Alan Rix, Coming to Terms: The Politics of Australia's Trade with Japan 1945-57 (Sydney: Allen \& Unwin, 1986), 209; Sekishita Monoru, Nichibei boueki masatsu to shokuryō mondai [Japan-US Trade Conflicts and Food Problem] (Tokyo: Dōbunkan shuppan, 1987), 197.

15. Shirakizawa, “Sengo shokuryō yu'nyū no teichaku to shokuseikatsu kaizen,” 18. 16. Wallerstein, Food for War-Food for Peace, 5.

17. Toma, The Politics of Food for Peace, 45; Kaufman, Trade and Aid, 151.

18. Wallerstein, Food for War-Food for Peace, 215.

19. Ito Atsushi, "Senji dōin, senryō kaikaku to sengo nihon nōsei" [Wartime Mobilization, Occupation Reform, and the Postwar Japanese Agricultural Policy], Nihonshi kenkyū 631 (Mar. 2015): 108.

20. Shibata Shigeki, "Chōsen sensōgo no Amerika no taigai enjo (MSA) to Nihon no kōkūki sangyō" [US Foreign Assistance to Japan (MSA) and the Japanese Aircraft Industry after the Korean War], Shakai keizai Shigaku 67, no. 2 (July 2001): 51.

21. Ōkurashō zaiseishi shitsu [Office of History of Finance, Ministry of Finance], 
ed., Shōwa zaisei shi: Shōwa 27-48 nendo [History of Finance in the Showa Period: FY 1952-1973], Vol. 11 (Tokyo: Tōyō keizai shinpōsha, 1999), 19; Nakakita Kōji, 1955 nen taisei no seiritsu [The Establishment of the 1955 System in Japanese Politics] (Tokyo: University of Tokyo Press, 2002), 60; Asai, "Sekai ginkō no tainichi seisaku no keisei," 22. 22. Department of State to American Embassy, Tokyo, Jan. 21, 1954, in Records of the U.S. Department of State Relating to the Internal Affairs of Japan 1950-1954 (Wilmington, DE: Scholarly Resources, 1986), reel 18; Ambassador Iguchi Sadao to Minister of Foreign Affairs, "MSA ni yoru komugi kaituke ni kansuru ken" [Purchase of US Wheat under the MSA Agreement], Jan. 8, 1954, E’2.3.1.4, Vol. 3, Diplomatic Archives of the Ministry of Foreign Affairs of Japan, Tokyo (hereafter DA-MOFAJ). On Australia's reaction, see Peterson, Agricultural Exports, Farm Income, and the Eisenhower Administration, 27.

23. Peterson, Agricultural Exports, Farm Income, and the Eisenhower Administration, 44; Hardin, Food and Fiber in the Nation's Politics, 29-30.

24. Stam, "The Effects of Public Law 480 on Canadian Wheat Exports," 808.

25. Nōrinshō [Ministry of Agriculture and Forestry], "Beikoku no kajō nōsanbutsu no ukeire ni tuite" [Acceptance of US Surplus Commodities], Feb. 13, 1954, E'2.3.1.4, Vol. 3, DA-MOFAJ.

26. "Memorandum," E’2.3.1.4, Vol. 7, DA-MOFAJ.

27. Ito Atsushi, "Dai 1ji PL 480 Title I kyōtei o meguru Nichi-Bei kōshō" [The Negotiations between the US and Japan Concerning the First PL 480 Title I Agreement], Rekishigaku kenkyū 1006 (Mar. 2021): 8. 
28. Hoshiro Hiroyuki, Ajia chiikishugi gaikō seisaku no yukue: 1952-1966 [The Rise and Fall of Japan's Regional Diplomacy: 1952-1966] (Tokyo: Bokutakusha, 2008), 119.

29. Aaron Forsberg, America and the Japanese Miracle: The Cold War Context of Japan's Postwar Economic Revival, 1950-1960 (Chapel Hill: University of North Carolina Press, 2000), 143.

30. Wallerstein, Food for War-Food for Peace, 187; Wayne D. Rasmussen and Jane M. Porter, "Strategies for Dealing with World Hunger: Post-World War II Policies," American Journal of Agricultural Economics 63, no. 5 (Dec. 1981): 815.

31. Akaneya Tatsuo, "1950 nendai ni okeru nihon no taigai keizai seisaku no tenkai: Nichi-Bei yojō nōsanbutsu kyōtei kara Nichi-Gō tsūshō kyōtei e" [The Development of Japanese Foreign Economic Policy in the 1950s: From the Japan-US Surplus Disposal Agreement to the Japan-Australia Commercial Treaty], Nenpo kindai Nihon kenkyū 15 (Dec. 1993): 74.

32. "Contribution to Study of Foreign Disposal of Surplus Agricultural Commodities," Aug. 12, 1955, in Confidential U.S. State Department Special Files, Japan 1947-1956, ed. Gregory Murphy (Bethesda: University Publications of America, 1990), reel 32 .

33. American Embassy, Canberra to the Department of State, "United States and Australian Negotiations with Japan,” Dec. 6, 1956, entry NARS A-1\#2, box 552, Foreign Agricultural Service, RG 166, National Archives and Records Administration II, College Park, MD (hereafter NARA II). 
34. Rix, Coming to Terms, 208-9; Akaneya, "1950 nendai ni okeru nihon no taigai keizai seisaku no tenkai," 85-86.

35. J. G. Crawford, Australian Trade Policy 1942-1966: A Documentary History (Canberra: Australian National University Press, 1968), 359.

36. Economic Planning Board, Japanese Government, Economic Survey of Japan (1955-1956) (Tokyo: Japan ECAFE Association, 1956), Annex 6.

37. Nakakita, 1955 nen taisei no seiritsu, 150-51; Hatano Sumio and Sato Susumu, Gendai nihon no tōnan ajia seisaku 1950-2005 [Japan's Policy toward Southeast Asia 1950-2005] (Tokyo: Waseda University Press, 2007), 29; see also Ruttan, United States Development Assistance Policy, 72.

38. Borden, The Pacific Alliance, 183.

39. In his explanation, Solt confused Section 550 and PL 480. Solt, The Untold History of Ramen, 75-77.

40. Yokoyama Hidenobu, Nihon mugi jukyū seisaku shiron [History of Japan's Wheat Supply and Demand Policy] (Tokyo: Hassakusha, 2002), 47, 54-55.

41. Ōiso Toshio, Konmei no naka no hōshoku [Satiation in Disorder] (Tokyo: Ishiyakushuppan, 1980), 165-71. Ōiso was director of the Nutrition Division of the MHW in the 1950s.

42. “Kome no mondai (shian) [Rice Problem (Draft)]," Mar. 9, 1955, E’2.3.1.4, Vol. 11, DA-MOFAJ.

43. "Kokurui no shijō chōsadan no tōashokoku eno haken ni kansuru ken" [Dispatch of the US Grain Mission to East Asia], Sept. 10, 1954, E’2.3.1.4, Vol. 6, DA-MOFAJ. 
44. Tokyo to Secretary of State, Oct. 10, 1954, entry NARS A-1\#2C, box 34, RG 166, NARA II.

45. "Zaikyō taishikan nōgyō attaché Ladejinsky raihō ni kansuru ken" [The Visit of Ladejinsky, Agricultural Attaché, American Embassy in Tokyo], Oct. 6, 1954, E’2.3.1.4, Vol. 7, DA-MOFAJ.

46. Ōiso, Konmei no naka no hōshoku, 199-203.

47. OWGL to FAS, "Quarterly Progress Report Dealing with Market Development Projects for Grain and Grain Products in the Far East (July 1, 1957 to September 30, 1957)," entry NARS A-1\#2, box 552, RG 166, NARA II.

48. OWGL to FAS, "Quarterly Progress Report Dealing with Market Development Projects for Grain and Grain Products in the Far East (July 1, 1957 to September 30, 1957)," entry NARS A-1\#2, box 552, RG 166, NARA II.

49. Adachi Iwao, Pan no Meiji 100nenshi [100 Years of Bread in Japan] (Tokyo: Pan no Meiji 100nenshi kankōkai, 1970), 473.

50. American Embassy, Tokyo to the Department of State, "Part II-Economic Section, Joint WEEKA (Weekly Economic Notes)," Apr. 15, 1955, entry NARS A-1\#2, box 553, RG 166, NARA II.

51. Nōrinshō [Ministry of Agriculture and Forestry], "Beikoku yojō nosanbutsu ukeire ni tomonau 104jō (a)kou no yen shiyō keikaku ni kansuru yōbōsho" [Request for the Use Plan of Yen Funds under PL 480 Sec. 104(a)], July 18, 1955, E’2.3.1.4-3, Vol. 1, DA-MOFAJ.

52. Tokyo to Secretary of State, July 21, 1955, entry NARS A-1\#2, box 553, RG 166, 


\section{NARA II.}

53. Vice-Minister of Agriculture and Forestry Hirakawa Mamoru to W. D. Termohlen, Sept. 8, 1955, E'2.3.1.4-3, Vol. 1, DA-MOFAJ.

54. Office of the Agricultural Attaché, American Embassy in Japan, "Summary of Market Development Program in Japan (As of December 1, 1957)," E'2.3.1.4-3, Vol. 4, DA-MOFAJ.

55. Joseph S. Evans Jr. to James J. Halsema, Mar. 22, 1956, in Murphy, ed., Confidential U.S. State Department Special Files, Japan 1947-1956, reel 36.

56. J. Graham Parsons to Noel Hemmendinger, Feb. 27, 1956, in Murphy, ed., Confidential U.S. State Department Special Files, Japan 1947-1956, reel 36.

57. American Embassy, Tokyo to the Department of State, "A Fresh Start with Japan," Sept. 21, 1956, in Amerika gasshūkoku tainichi seisaku bunsho shūsei: Nichibei gaikō bōei mondai 1956nen 2kan [Documents on the US Policy toward Japan: Documents Related to Diplomatic and Military Matters 1956, vol. 2], eds. Ishii Osamu and Ono Naoki (Tokyo: Kashiwa shobō, 1999), 272-73.

58. J. Graham Parsons to Noel Hemmendinger, Feb. 27, 1956, in Murphy, ed., Confidential U.S. State Department Special Files, Japan 1947-1956, reel 36.

59. Tokyo to Secretary of State, May 27, 1957, entry NARS A-1\#2, box 553, RG 166, NARA II.

60. Ahlberg, Transplanting the Great Society, 26-27n39. See also George S. McGovern, War against Want: America's Food for Peace Program (New York: Walker and Company, 1964), 25; Fujihara, Kyūshoku no rekishi, 165-66. The Japanese government 
disapproved of the US request for a market survey of poultry in November 1957. "Keiniku, shichimenchō, keiran no shijō chōsa ni tsuite bei minkanjin tou no hounichi no ken" [American Mission to Japan concerning a Market Survey of Chicken, Turkey, and Egg], Nov. 15, 1957, E’2.3.1.4-3, Vol. 4, DA-MOFAJ.

61. Tokyo to Secretary of State, Oct. 20, 1956, entry NARS A-1\#2, box 553, RG 166, NARA II.

62. Nōrinshō daijin kanbō sōgō shokuryō shōhi seisaku shitsu [General Food Policy Bureau, Ministry of Agriculture and Forestry], "Beikoku yojō nōsanbutsu shijō kaitaku (104jō (a)kou) no tameno yen shikin shiyō keikaku an (kaitei) (beikoku gawa teian)" [US Revised Plan for Yen Funds under PL 480 Sec. 104(a)], Nov. 27, 1955, E’2.3.1.4-3, Vol. 1, DA-MOFAJ.

63. Tokyo to Secretary of State, Mar. 13, 1956, entry NARS A-1\#2, box 547, RG 166, NARA II.

64. Mordecai Ezekiel, "Apparent Results in Using Surplus Food for Financing Economic Development," Journal of Farm Economics 40, no. 4 (Nov. 1958): 920.

65. American Consulate General, Kobe-Osaka to the Department of State, "The Bread Industry in Japan," Oct. 29, 1958, entry NARS A-1\#2, box 555, RG 166, NARA II. 66. "Pan'yasan wa ōyowari. Beishoku katei fueru Ippou” [Difficult Conditions of Bakeries. Increase in Rice-eating Households], Yomiuri Shimbun, Feb. 4, 1957, 7. Regarding this article, the agricultural attaché commented that the meaning of "bankrupt" was questionable. American Embassy, Tokyo to the USDA, "Special Report-Japanese Bread Consumption Decreases," Feb. 25, 1957, entry NARS A-1\#2, box 547, RG 166, 


\section{NARA II.}

67. American Embassy, Tokyo to the USDA, "Special Report—Japanese Bread Consumption Decreases," Feb. 25, 1957, entry NARS A-1\#2, box 547, RG 166, NARA II. Ever since the enactment of the Food Control Law in 1942, rice and wheat had come under state control. The Japanese government sold imported wheat above world market price to safeguard domestic wheat; the import markup went into the national treasury.

68. American Embassy, Tokyo to the USDA, "End-uses of Various Types of Wheat in Japan,” Mar. 22, 1960, entry NARS A-1\#2, box 548, RG 166, NARA II.

69. American Consulate General, Kobe-Osaka to the Department of State, "Wet Noodle Industry," Oct. 10, 1958, entry NARS A-1\#2, box 547, RG 166, NARA II.

70. American Consulate General, Kobe-Osaka to the Department of State, "Japan International Trade Fair, Osaka, 1958, " May 20, 1958, entry NARS A-1\#2, box 559, RG 166, NARA II. The report stated that the star attraction of the fair was a model of Sputnik II and that the most popular pavilion was that of the USSR. See also "Hitome wo hiku soren kan”[Eye-catching Soviet Pavilion], Yomiuri Shimbun, Apr. 11, 1958, 9.

71. Regarding a change in the Japanese eating habits, Cwiertka pointed out that the "decline in rice consumption in Japan was not the result of a shift from rice-centred to bread-centred diet," and that "[D]espite the evident impact of the school lunch programme on the food preferences of the post-war generations of Japanese, it was by no means responsible for the popularization of American cuisine.” Katarzyna J. Cwiertka, Modern Japanese Cuisine: Food, Power and National Identity (London: Reaktion Books, 2006), $158,164$. 
72. Yokoyama, Nihon mugi jukyū seisaku shiron, 198.

73. Economic Planning Agent, Japanese Government, Economic Survey of Japan (1970-1971) (Tokyo: Japan Times, 1971), 158.

74. In the Food Control Special Account FY1960, the estimated profit and loss were as follows: losses of $\$ 55$ million from domestic rice and $\$ 32.2$ million from domestic wheat and barley; and a profit of $\$ 57.2$ million from imported food (mostly wheat). American Embassy, Tokyo to Secretary of State, "Program and Policy Difficulties in Japanese Agriculture," Nov. 9, 1960, entry NARS A-1\#2, box 548, RG 166, NARA II.

75. American Embassy, Tokyo to the USDA, "Special Report: U.S.-Japanese Inter-governmental Wheat Discussions," Apr. 17, 1961, entry NARS A-1\#2, box 548, RG 166, NARA II. See also Takashima, Nihon shinkō Amerika komugi senryaku, 132.

76. Under the Food Control Law, all rice crop except the amount intended for home consumption was purchased by the Japanese government. In the late 1960s the heavy deficit in the Food Control Special Account caused by the loss margin on the price of rice and rice surplus developed into a political problem. Ricard H. Moore, Japanese Agriculture: Patterns of Rural Development (Boulder: Westview Press, 1990), 231-33.

77. Adachi, Pan no Meiji 100nenshi, 487.

78. Based on econometric analysis, an economist concluded that the hard wheat demand in Japan increased as a result of income growth and a decline in the relative government selling price of wheat to rice. Ishizaki Noriyuki, "Shoku no yōfūka ni okeru komugi jukyū henyō no seisaku bunseki” [Policy Analysis of the Wheat Market Transformation in the Process of Food Life Westernization in Japan], Nōringyō mondai 
kenkyü 36, no. 1 (June 2000), 24.

79. “Japan's Relations with Communist China," Nov. 4, 1954, in Confidential U.S. State Department Special Files, Northeast Asia 1943-1956, ed. Gregory Murphy (Bethesda: University Publications of America, 1990), reel 13.

80. Schaller, "Securing the Great Crescent"; Borden, The Pacific Alliance, 93.

81. "A Survey of Elements Necessary to Facilitate the Economic Development of Southeast Asia," Oct. 12, 1954, in Murphy, ed., Confidential U.S. State Department Special Files, Northeast Asia 1943-1956, reel 13.

82. At the talks with Prime Minister Yoshida, Secretary of State John F. Dulles presented a cheap Japanese shirt copied from better-quality cloth made in the United States and emphasized that trade with Southeast Asia was a better prospect for Japan. "United States Summary Minutes of Meeting," Nov. 9, 1954, in Foreign Relations of the United States, 1952-1954, China and Japan, Vol. 14, Pt. 2, edited by John P. Glennon (Washington, DC: Government Printing Office, 1985), 1782.

83. Akita Shigeru, Teikoku kara kaihatsu enjo e [From Empires to Development] (Nagoya: University of Nagoya Press, 2017), 150.

84. Ōkurashō zaiseishi shitsu, Shōwa zaisei shi: Shōwa 27-48 nendo, Vol. 11, 522.

85. “United States-Japan Trade,” Sept. 21, 1955, in Murphy, ed., Confidential U.S. State Department Special Files, Japan 1947-1956, reel 33.

86. "Minutes of Meeting Interagency Staff Committee on Agricultural Surplus Disposal," Oct. 28, 1954, entry UD-WW21, box 1, RG 166, NARA II.

87. "Minutes of Cabinet Meeting," Nov. 5, 1954, in Glennon, ed., Foreign Relations 
of the United States, 1952-1954, China and Japan, Vol. 14, Pt. 2, 1770-71.

88. "Proposed United States Policy Regarding Rice Exports to Asia,” Apr. 12, 1955, in Murphy, ed., Confidential U.S. State Department Special Files, Japan 1947-1956, reel 32.

89. "US Policy with Respect to Export of Rice to Asia," Apr. 29, 1955, in Murphy, ed., Confidential U.S. State Department Special Files, Japan 1947-1956, reel 32.

90. "Recent Developments on Rice in Southeast Asia," June 23, 1955, in Murphy, ed., Confidential U.S. State Department Special Files, Japan 1947-1956, reel 32.

91. "Conference with Minister Kono on Japanese rice purchases from the United States," May 19, 1956, Central Decimal Files 411.9441/5-1956, box 1796, RG 59, NARA II.

92. FAS “Section 104(a) Project Statement for Rice in Japan,” Jan. 11, 1957, E’2.3.1.4-3, Vol. 4, DA-MOFAJ.

93. "Shōwa 32 1gatsu 21nichi no kaigi (202gō) (Intergovernmental)" [Intergovernmental meeting on Jan. 21, 1957 (no. 202)], E’2.3.1.4-3, Vol. 4, DA-MOFAJ. 94. Tokyo to Secretary of State, May 27, 1957, entry NARS A-1\#2, box 553, RG 166, NARA II.

95. "Yojō nōsanbutsu kyōtei ni motozuku tsumitate yen no beigawa shiyōbun ni kansuru ken" [US Plan for Utilizing Yen Funds under the PL 480], June 17, 1957, E’2.3.1.4-3, Vol. 4, DA-MOFAJ.

96. “Status of Market Development Funds as of September 30, 1958,” E’2.3.1.4-3, Vol. 4, DA-MOFAJ. 
97. Singer, Wood, and Jennings, Food Aid, 189.

98. Singer, Wood, and Jennings, Food Aid, 106.

99. George S. McGovern, the first director of the Food for Peace Office, recalled that "[O]perations in Hong Kong were at first hampered by the Chinese dietary traditions that led them to frown on our milk powder, cornmeal, and flour" and that "[T]his problem has been largely solved by the development of a simple noodle-making machine to convert our food into a form more suited to the oriental taste." McGovern, War against Want, 39. 


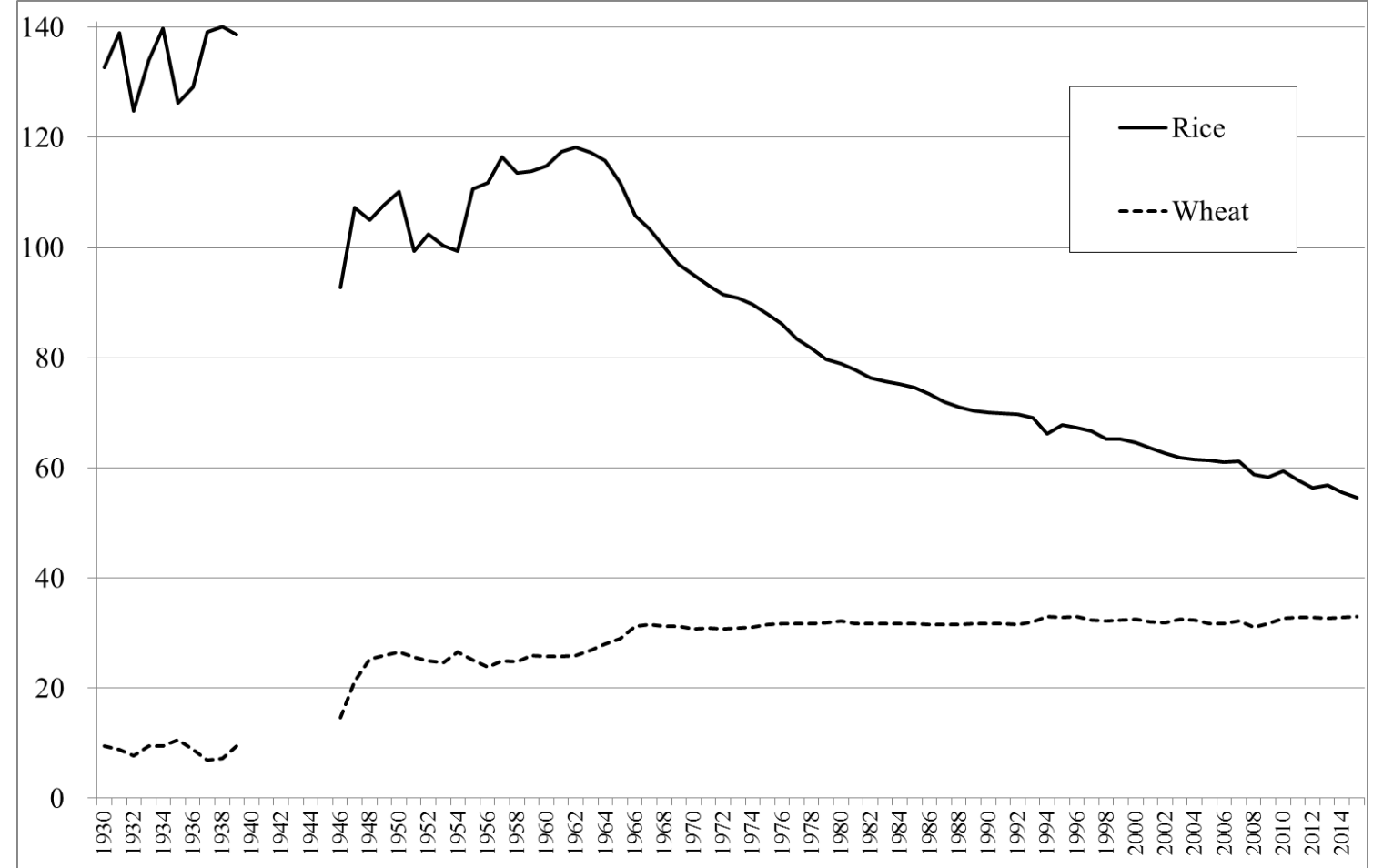

Figure 1. Per Capita Consumption of Rice and Wheat in Japan, 1930-2015 (kilograms).

Sources: Nōrin daijin kanbō chōsaka [Research Division, Ministry of Agriculture and Forestry],

Shokuryō juyō ni kansuru kiso tōkei [Basic Statistics on Food Demand] (Tokyo: Nōrin tōkei kyōkai, 1976), 52-53, 115 and Nōrin suisan shō [Ministry of Agriculture, Forestry and Fisheries], Heisei 28nendo shokuryō juykū hyō [Food Balance Sheet FY2016], http://www.maff.go.jp/j/zyukyu/fbs/ (Accessed Sep. 7, 2019). 


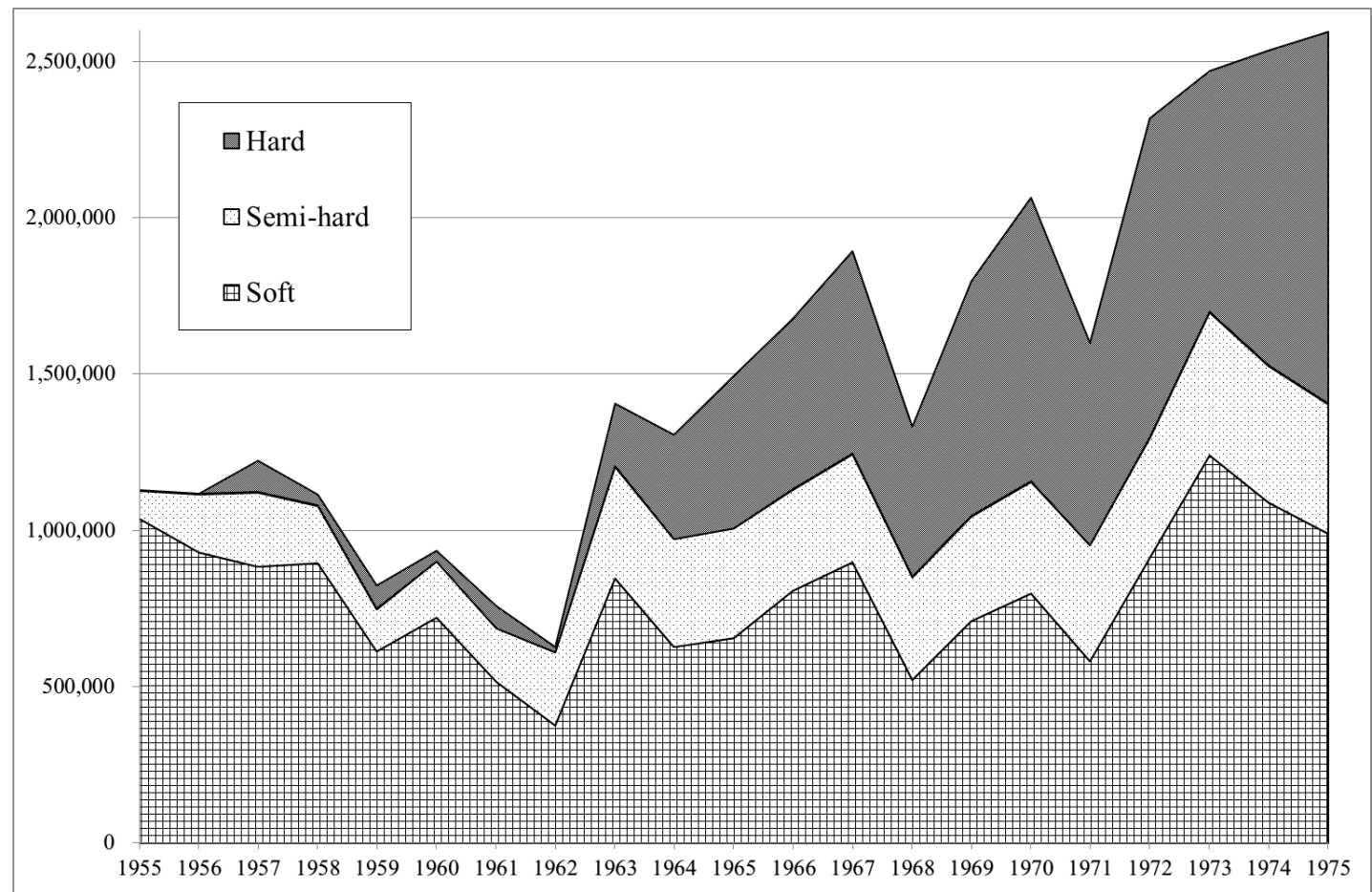

Figure 2. US Wheat Exports to Japan, 1955-1975 (metric tons).

Source: Shokuryōchō [The Food Agency of the MAF], Shokuryō kanri tōkei nenpō [Annual Report of Statistics on Food Control], various years. 
Table 1. End-of-Year Carryover, 1951-1956.

\begin{tabular}{|l|r|r|r|r|r|r|}
\hline & 1951 & 1952 & 1953 & 1954 & 1955 & 1956 \\
\hline Rice (in Million Cwt.) & 2.0 & 1.5 & 7.5 & 26.7 & 35.5 & 20.0 \\
\hline Wheat (in Million Bushels) & 256.0 & 605.5 & 933.5 & $1,036.2$ & $1,033.5$ & 908.8 \\
\hline
\end{tabular}

Source: Willard W. Cochrane and Mary E. Ryan, American Farm Policy, 1948-1973 (Minneapolis:

University of Minnesota Press), 203, 245.

Table 2. Japan's Volume of Wheat Imports, 1955-1960 (1,000 metric tons).

\begin{tabular}{|l|l|r|r|r|r|r|r|}
\hline & & 1955 & 1956 & 1957 & 1958 & 1959 & 1960 \\
\hline US & Soft & 1,039 & 930 & 884 & 895 & 614 & 722 \\
& Semi-hard & 88 & 184 & 237 & 183 & 134 & 179 \\
\hline & Hard & 0 & 0 & 100 & 35 & 73 & 33 \\
\hline Canada & Total & 1,127 & 1,115 & 1,221 & 1,112 & 821 & 933 \\
\hline & Hard & 753 & 911 & 829 & 860 & 1,070 & 1,069 \\
\hline Australia & Total & 753 & 911 & 829 & 860 & 1,070 & 1,069 \\
\hline & Soft & 0 & 0 & 151 & 110 & 203 & 54 \\
\hline & Semi-hard & 234 & 120 & 0 & 12 & 50 & 10 \\
\hline Others & Total & 234 & 120 & 151 & 122 & 253 & 65 \\
\hline Grand Total & Total & 63 & 42 & 3 & 3 & 23 & 65 \\
\hline
\end{tabular}

Note: The data on wheat varieties is available from 1955 onward.

Source: Shokuryōchō [The Food Agency of the MAF], Shokuryō kanri tōkei nenpō [Annual Report of Statistics on Food Control], various years. 


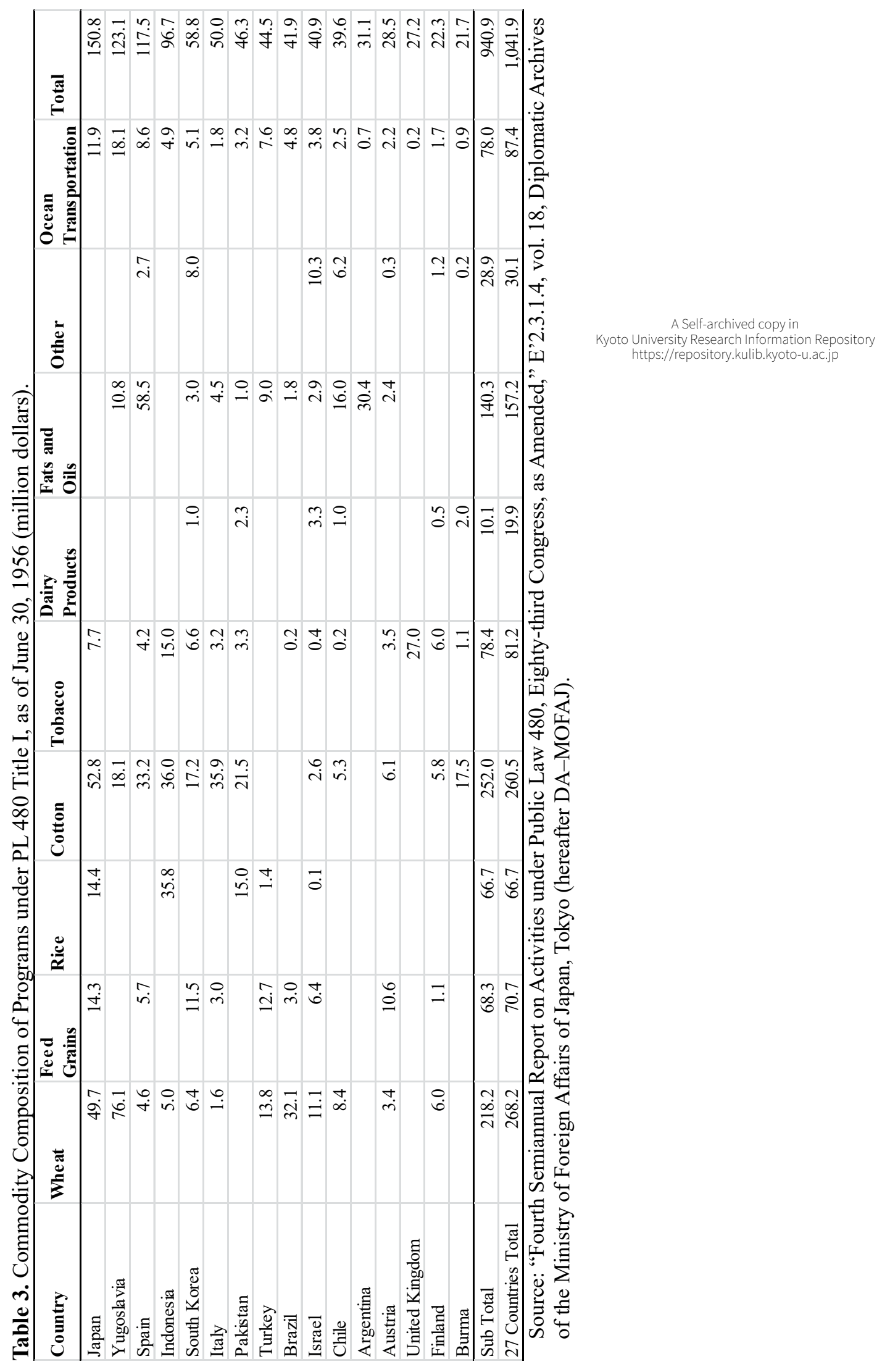




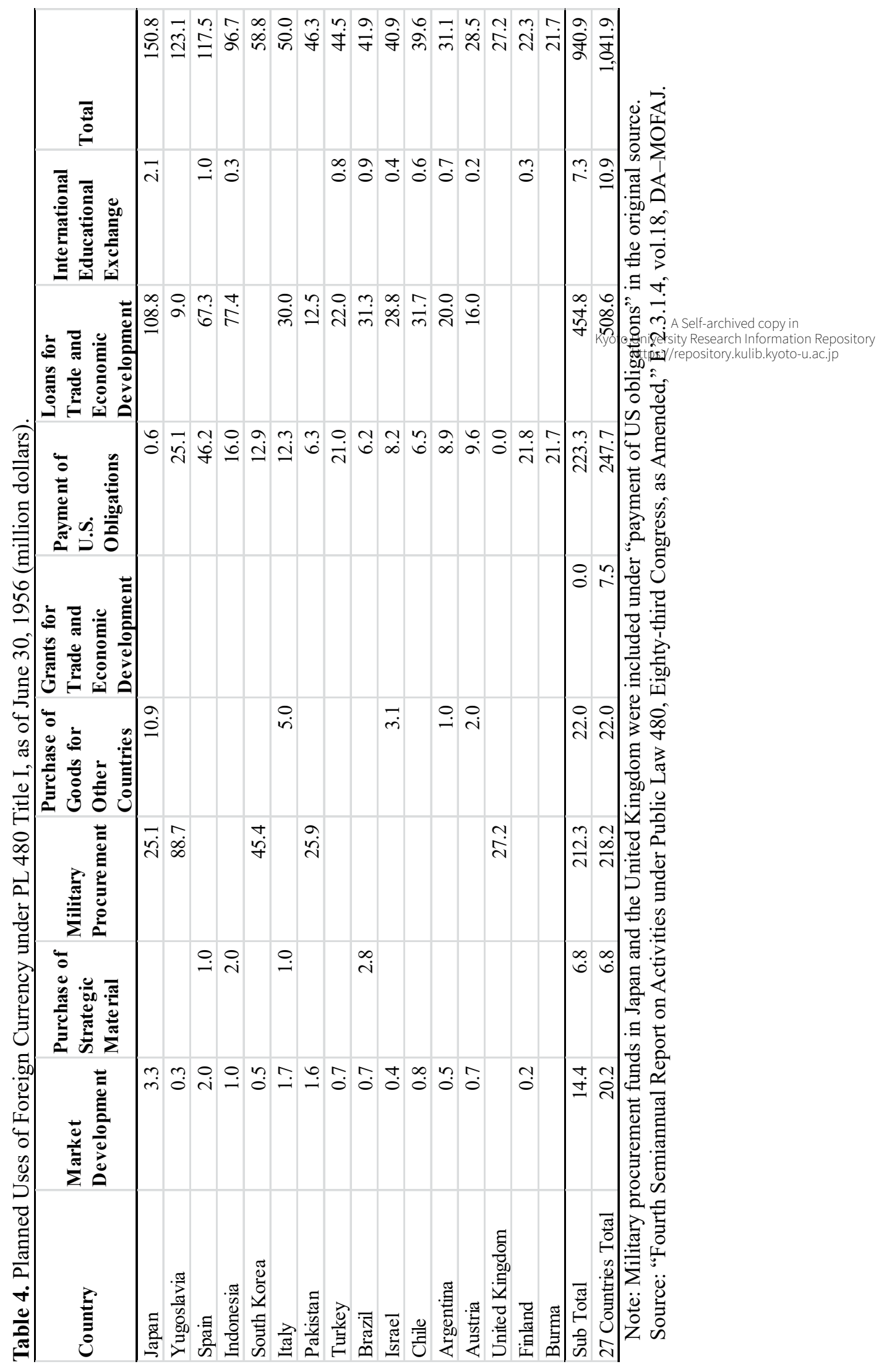




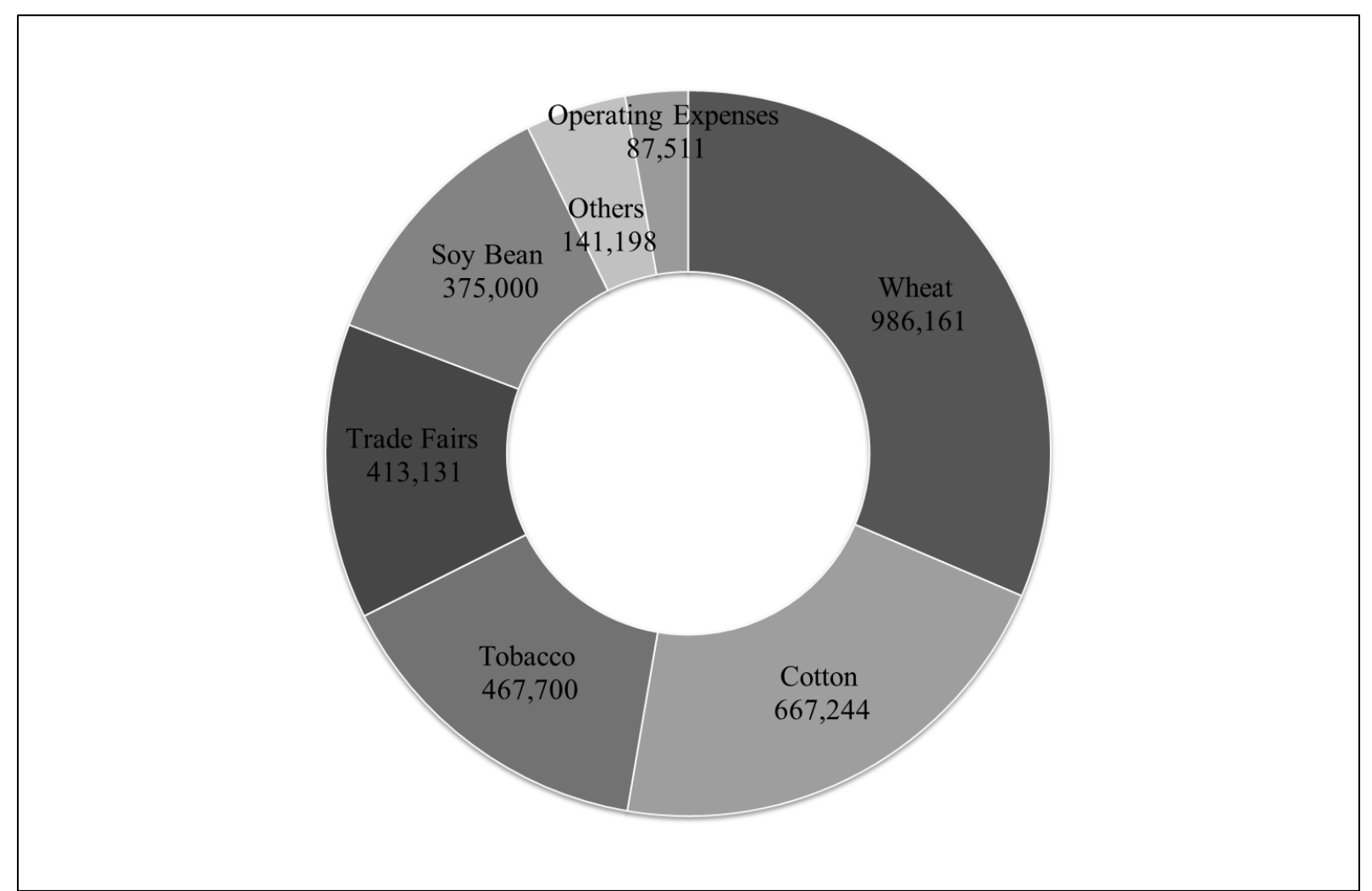

Figure 3. Japanese Market Development Funds as of September 30, 1958 (dollar equivalents). Source: "Status of Market Development Funds as of September 30, 1958," E'2.3.1.4-3, vol. 4, DA-MOFAJ. 


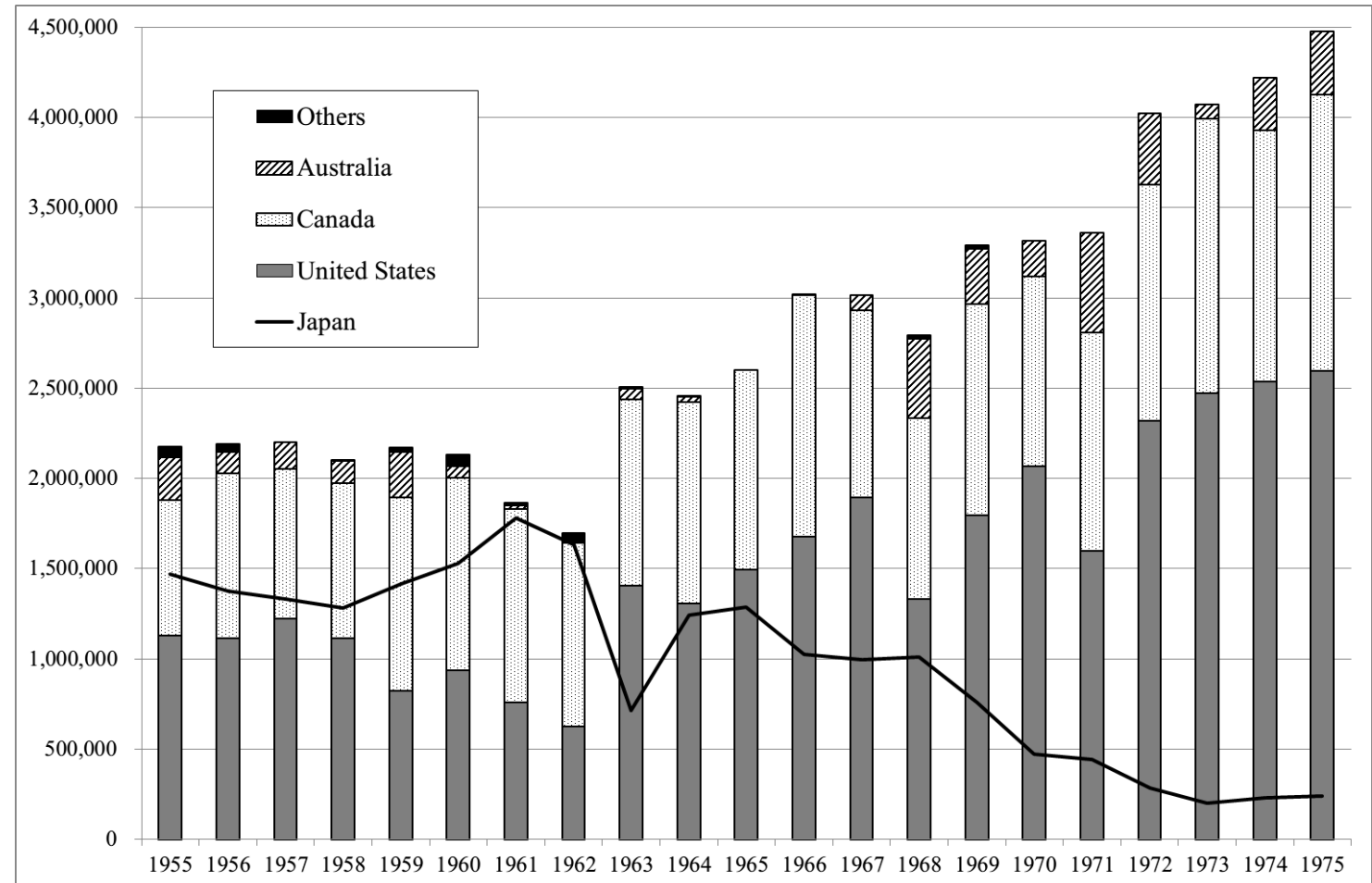

Figure 4. Japan's Domestic Production and Imports of Wheat, 1955-1975 (metric tons).

Source: Shokuryōchō [The Food Agency of the MAF], Shokuryō kanri tōkei nenpō [Annual Report of Statistics on Food Control], various years. 


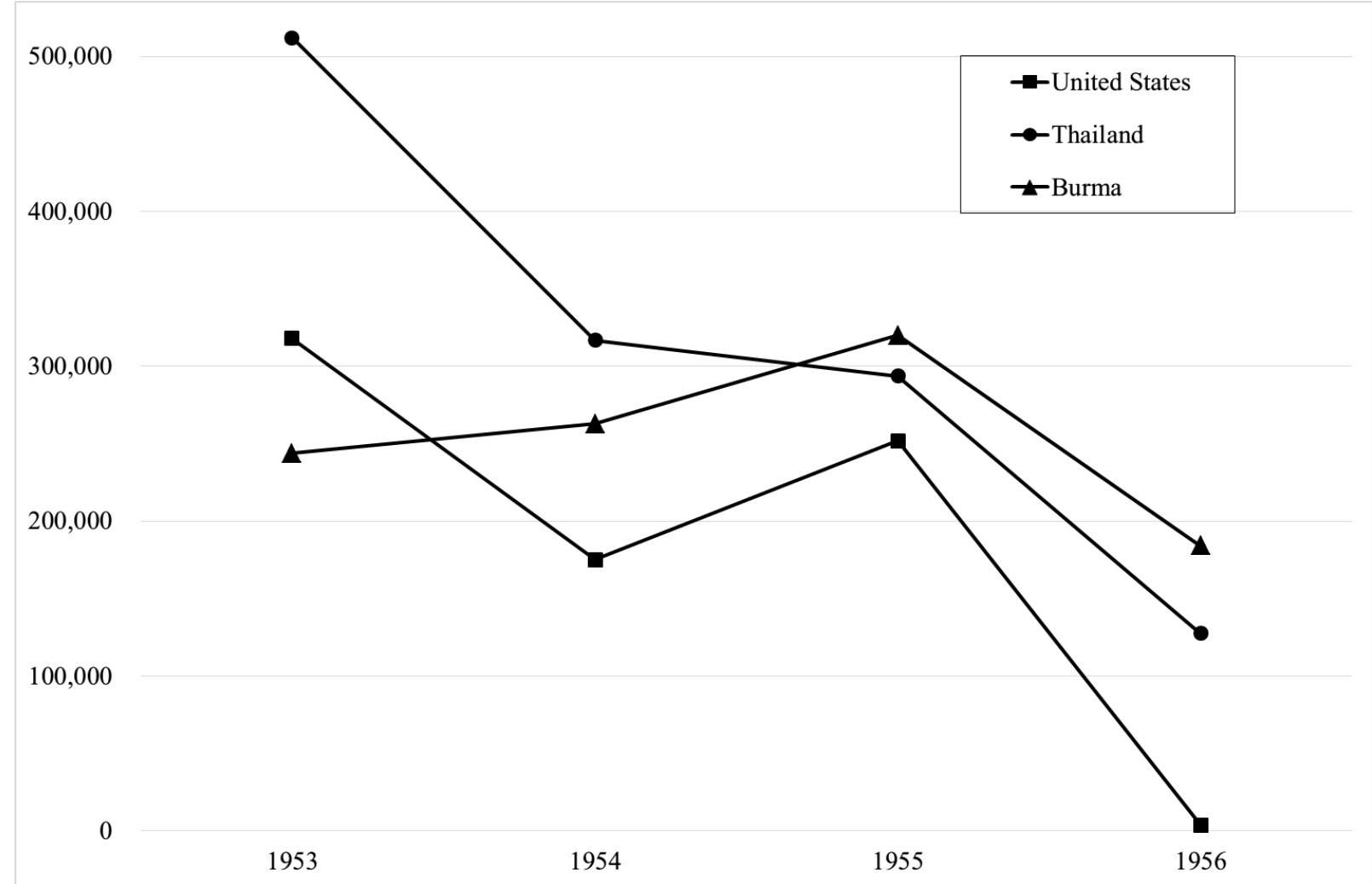

Figure 5. Japan's Volume of Rice Imports from Thailand, Burma, and the United States, 1953-1956 (metric tons).

Source: Shokuryōchō [The Food Agency of the MAF], Shokuryō kanri tōkei nenpō [Annual Report of Statistics on Food Control], various years. 


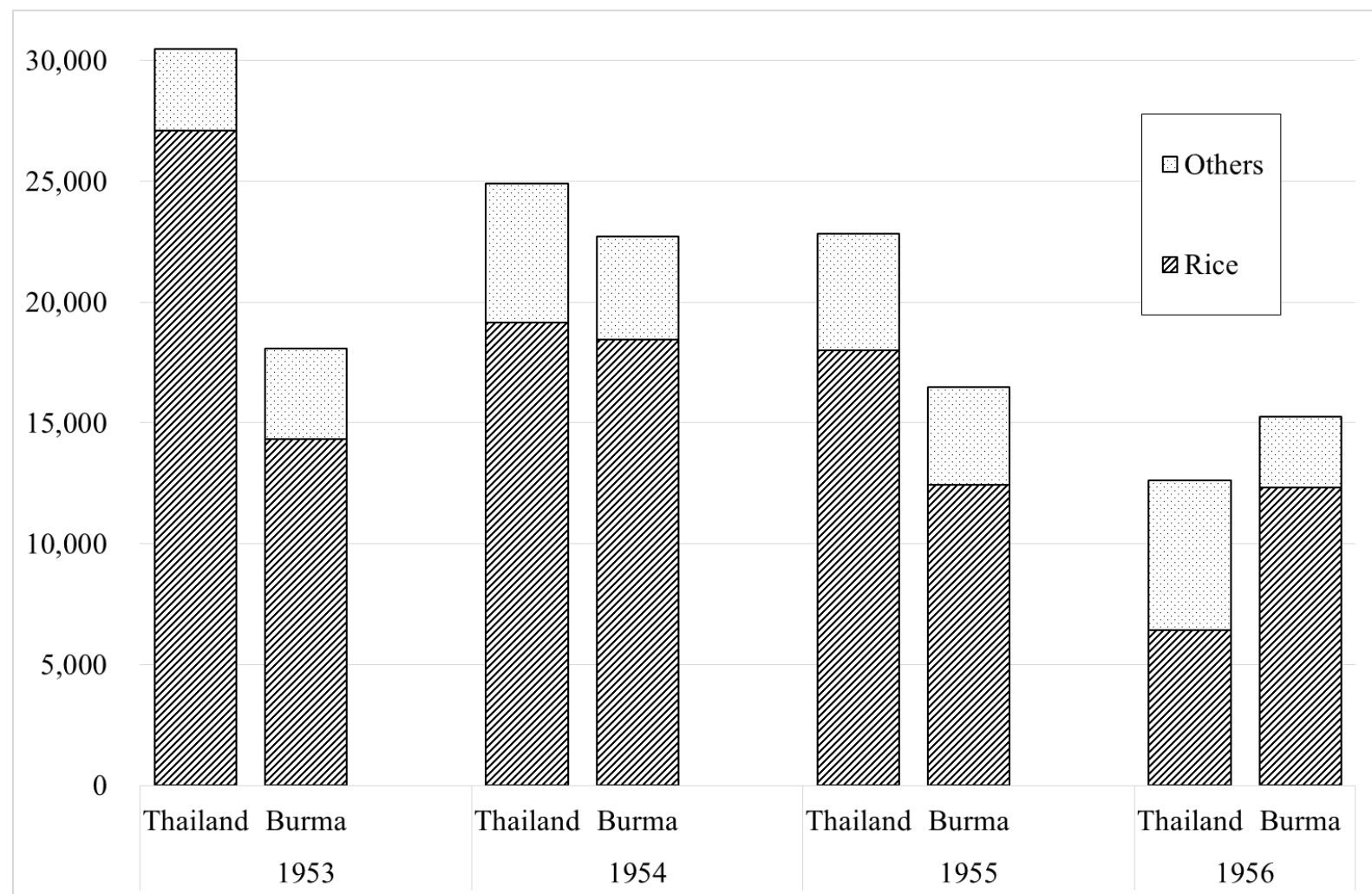

Figure 6. Japan's Imports from Thailand and Burma (in monetary value), 1953-1956 (million yen). Source: Ōkurashō shuzeikyoku zeikanbu chōsa tōkeika [Statistical Survey Division, Customs Service, Tax Bureau of Ministry of Finance], Gaikoku bōeki gaikyō [The Summary Report on Trade of Japan] nos. 18, 30, $42,54$. 